\title{
THE VOLUME OF DISTRIBUTION OF MANNITOL AS A MEAS- URE OF THE VOLUME OF EXTRACELLULAR FLUID, WITH A STUDY OF THE MANNITOL METHOD ${ }^{1}$
}

\author{
By J. RUSSELL ELKINTON \\ (From the Department of Internal Medicine, Yale University School of Medicine, New Haven)
}

(Received for publication May 5, 1947)

The clearance of mannitol has been advocated by Smith and his coworkers as a measure of glomerular filtration rate (1). Newman, Bordley and Winternitz (2) modified Smith's procedure by calculating the clearance of mannitol from the rate of fall of concentration in serum after a single injection of the substance and suggested that the rate of glomerular filtration is more logically related to the volume of extracellular fluid than to body surface area. They also presented evidence that the volume of distribution of mannitol is of approximately the same magnitude as this fluid compartment.

The thesis of Newman, Bordley and Winternitz that the clearance of mannitol can be calculated from the fall in serum concentration alone is valid only if mannitol reaches a constant volume of distribution in the body. The determination of the volume of distribution rests on the following assumptions: (1) that mannitol is neither formed nor destroyed in the body, (2) that it is distributed uniformly throughout some portion of the body water, (3) that its concentration in water of serum is a fair sample of its concentration throughout this portion, and (4) that it is excreted solely in the urine (3). It is the purpose of this investigation to determine whether the apparent volume of distribution of mannitol meets the above basic assumptions, and to study the relation of this volume to that of extracellular fluid.

Such a study requires a precise knowledge of the errors involved in the determination of mannitol. For this reason the method of determination and its accuracy were investigated in this laboratory and certain modifications introduced to minimize the error.

1 Aided by a grant from the Fluid Research Fund of Yale University.

\section{METHODS}

The method of determination of mannitol used was that introduced by Smith, Finkelstein, and Smith (1), with modifications as indicated below. The method involves the oxidation of glucose-free filtrate with the reduction of a known excess of $\mathrm{KIO}_{4}$, and quantitation of the remaining $\mathrm{KIO}_{4}$ by iodometric titration with $\mathrm{Na}_{2} \mathrm{~S}_{2} \mathrm{O}_{3}$.

Reagents.

Acid cadmium sulfate: 34.68 grams $3 \mathrm{CdSO}_{4} .8 \mathrm{H}_{2} \mathrm{O}$ and $169.10 \mathrm{ml} .1 \mathrm{NH}_{2} \mathrm{SO}_{4}$ made up to $1000 \mathrm{ml}$. $\mathrm{H}_{2} \mathrm{O}$.

Sodium hydroxide $1.1 \mathrm{~N}$.

Baker's starch-free yeast : approximately 20 per cent suspension.

Mannitol ${ }^{2}$ standard solution: $100 \mathrm{mgm}$. per $100 \mathrm{ml}$. Acid potassium periodate: $0.60 \mathrm{gram} \mathrm{KIO}_{4}$ and 20 ml. conc. $\mathrm{H}_{2} \mathrm{SO}$, made up to $1000 \mathrm{ml} . \mathrm{H}_{2} \mathrm{O}^{3}$

Concentrated $\mathrm{KI}$ : approximately 50 per cent solution. Amylose: 1 per cent solution.

Sodium thiosulfate: $0.005 \quad \mathrm{Na}_{2} \mathrm{~S}_{2} \mathrm{O}_{3}$ made from $0.1 N$ stock solution.

Analysis in serum. The sample of serum is rendered glucose-free by fermentation with freshly washed starchfree baker's yeast in approximately 20 per cent suspension. To $2 \mathrm{ml}$. of serum in a $150 \times 20 \mathrm{~mm}$. pyrex tube are added $6 \mathrm{ml}$. of the yeast suspension which is thoroughly shaken before the withdrawal of each aliquot. The tubes are stoppered, shaken 3 times during 15 minutes and centrifuged. The exact extracellular fluid content of the yeast suspension is determined by centrifugation in a Wintrobe hematocrit tube. In 19 comparisons of the extracellular fluid content of the yeast suspension before and after yeasting a large number of serum and urine ali-

2 The mannitol was supplied through the courtesy of Sharp and Dohme, Inc.

8 Since this study was done Barker and Clark (15) have reported that free para-aminohippuric acid (PAH) reduces acid $\mathrm{KIO}_{4}$ and so introduces an error in the determination of mannitol when present in the same biological media. These workers obviated the error by acetylating the $\mathrm{PAH}$ and acidifying the $\mathrm{KIO}_{4}$ solution with acetic instead of sulfuric acid. While such an error does not affect the study reported here, it must be considered when clearances of mannitol and PAH are measured simultaneously. 
quots, the mean difference was insignificant, being only 0.14 per cent with a maximum difference of 0.3 per cent. Filtrates of serum containing concentrations of mannitol of $50 \mathrm{mgm}$. per cent or less (including serum and reagent blanks) are fortified by the addition of a 2-ml. aliquot of $100 \mathrm{mgm}$. per cent aqueous solution of mannitol added to the $2 \mathrm{ml}$. of serum and $6 \mathrm{ml}$. of yeast. Filtrates of serum containing concentrations of 150 to $175 \mathrm{mgm}$. per cent and 175 to $200 \mathrm{mgm}$. per cent similarly are diluted with $2 \mathrm{ml}$. and $4 \mathrm{ml}$. of water, respectively. Failure to fortify or dilute resulted in increase of error: in 6 unfortified known solutions of mannitol in serum the average deviation was found to be $+3.3 \mathrm{mgm}$. per cent, and in 3 undiluted solutions it was $\mathbf{- 5 . 0} \mathrm{mgm}$. per cent.

Four ml. of the supernatant yeasted serum are pipetted directly from the centrifuge tube into a similar tube containing $6 \mathrm{ml}$. of cadmium sulfate. To this are added $2 \mathrm{ml}$. of $1.1 \mathrm{~N} \mathrm{NaOH}$, the tubes are stoppered, shaken several times during 10 minutes, and centrifuged. The supernatant fluid is filtered through washed absorbent cotton (plugged in the neck of a glass funnel). Duplicate 2-ml. aliquots of the cadmium filtrate are pipetted into a pyrex tube $(200 \times 25 \mathrm{~mm}$.) containing exactly $5 \mathrm{ml}$. of KIO, measured from an automatic pipette. Glass tears are placed in the tubes which are then heated in a boiling water bath for exactly 20 minutes. At the end of this time the tubes in the racks are transferred directly to a bath of ice water $\left(5^{\circ} \mathrm{C}\right.$. $)$ in which they are kept until titrated. Cooling in a water bath at room temperature $\left(25^{\circ}\right.$ C. $)$ definitely permits continued oxidation-reduction and results in false high values for mannitol if an hour or more elapses before titration: in 13 known solutions of serum cooled at room temperature the average deviation was $+4.3 \mathrm{mgm}$. per cent.

The tubes and glass tears are washed down with water. Immediately before starting the titration about $1 \mathrm{ml}$. of approximately 50 per cent $\mathrm{KI}$ is added to each tube. This $\mathrm{KI}$ must be made up freshly each day. The partially reduced $\mathrm{KIO}_{4}$, stirred with $\mathrm{CO}_{2}$ bubbles, is titrated by means of a Bang burette equipped with a B-D needle tip for immersion titration, with $0.005 N \quad \mathrm{Na}_{2} \mathrm{~S}_{2} \mathrm{O}_{3}$ prepared freshly each day from a factored stock solution of $0.1 \mathrm{~N}$ $\mathrm{Na}_{2} \mathrm{~S}_{2} \mathrm{O}_{3}$. This burette must never be washed with dichromate cleaning solution. Traces of dichromate remaining after the routine 5 or 6 rinsings reacted with the $\mathrm{Na}_{2} \mathrm{~S}_{2} \mathrm{O}_{3}$ and were the largest single source of error between duplicate titrations. Approximately $0.5 \mathrm{ml}$. of 1 per cent amylose solution is added when the titration is within $0.25 \mathrm{ml}$. to $0.15 \mathrm{ml}$. of the endpoint. The endpoint can be read to $0.005 \mathrm{ml}$.

To calculate the concentration of mannitol it is first necessary to determine the amount present in the solution titrated. This value which is $\mathrm{V}$ in Equation 1 below, varies according to whether or not $2 \mathrm{ml}$. of standard solution of mannitol or 2 or $4 \mathrm{ml}$. of water are added to the yeasting solution and also according to the extracellular fluid content $(\mathrm{h})$ of the 6 -ml. aliquot of the particular yeast suspension used:

$$
\begin{aligned}
& \text { (a) } \mathrm{V}=1.33 \text { per }(2+6 \mathrm{~h}) \\
& \text { (b) } \mathrm{V}=1.33 \text { per }(4+6 \mathrm{~h}) \\
& \text { (c) } \mathrm{V}=1.33 \text { per }(6+6 \mathrm{~h})
\end{aligned}
$$

Each $1 \mathrm{ml}$. of $0.005 \mathrm{~N} \mathrm{Na}_{2} \mathrm{~S}_{2} \mathrm{O}_{3}$ titrated by difference is equivalent to $0.092 \mathrm{mgm}$. of mannitol in the solution titrated. The concentration of mannitol (M) in mgm. per $100 \mathrm{ml}$. of the solution oxidized by $\mathrm{KIO}_{4}$ is :

$$
\mathrm{M}=\frac{9.2 \mathrm{f}(\mathrm{A}-\mathrm{B})}{\mathrm{V}}, \quad \text { Equation } 1
$$

where: $\mathrm{A}=$ No. of $\mathrm{ml}$. of $\mathrm{Na}_{2} \mathrm{~S}_{2} \mathrm{O}_{3}$ titrated against the blank $\mathrm{KIO}_{4}$ solution.

$\mathrm{B}=$ No. of ml. of $\mathrm{Na}_{2} \mathrm{~S}_{2} \mathrm{O}_{3}$ titrated against the reduced $\mathrm{KIO}_{4}$.

$\mathrm{f}=$ factor of the $0.005 \mathrm{~N} \mathrm{Na}_{2} \mathrm{~S}_{2} \mathrm{O}_{3}$.

$\mathrm{V}=$ volume in ml. of the known solution added to the $\mathrm{KIO}_{4}$

Substituting $\mathrm{V}$ as calculated above, $\mathrm{M}$ is calculated as follows :

(a) $\mathrm{M}=6.9(2+6 \mathrm{~h}) \mathrm{f}(\mathrm{A}-\mathrm{B})$, if no standard solution or water is added;

(b) $\mathrm{M}=6.9(4+6 \mathrm{~h}) \mathrm{f}(\mathrm{A}-\mathrm{B})$, if $2 \mathrm{ml}$. of standard solution or water is added;

(c) $\mathrm{M}=6.9(6+6 \mathrm{~h}) \mathrm{f}(\mathrm{A}-\mathrm{B})$, if $4 \mathrm{ml}$. of standard solution or water is added.

These equations (Equations 2, 3, 4) are the basic ones used to calculate the concentration of mannitol in serum or urine. Where $2 \mathrm{ml}$. of $100 \mathrm{mgm}$. per cent standard solution of mannitol has been added, 100 must be subtracted from the result. In all serum determinations the total serum blank must be subtracted from $\mathrm{M}$ as determined in these equations, to give the true value in serum. This blank is the value for non-fermentable reducing substance in the blank serum (net serum blank) plus the reagent blank. The reagent blank is the value for such substance in the yeast suspension and the cadmium sulfate and sodium hydroxide precipitating reagents. In all sera from fasting subjects the average for the total blank was $11.7 \mathrm{mgm}$. per cent with a range of 7.3 to $16.0 \mathrm{mgm}$. per cent, while the average net serum blank was $11.3 \mathrm{mgm}$. per cent with a range of 7.3 to $15.1 \mathrm{mgm}$. per cent. In 14 determinations the average reagent blank was +0.4 $\mathrm{mgm}$. per cent with a range of -3.0 to $+4.7 \mathrm{mgm}$. per cent.

In the analysis of 21 solutions of mannitol in serum of known concentrations between 25 and $200 \mathrm{mgm}$. per cent, the results of the observed concentrations were as follows: standard deviation $= \pm 1.2 \mathrm{mgm}$. per cent, average deviation $=0.9 \mathrm{mgm}$. per cent, maximum deviation $=2.6$ mgm. per cent. The mean difference between 54 pairs of duplicate titrations was $0.023 \mathrm{ml}$.

Analysis in urine. Urine is analyzed for mannitol in the same manner as serum, including the yeasting and precipitation. The only differences lie in the preliminary dilution of the urine and in the calculation of the blanks. 
The high concentrations of mannitol in urine necessitate dilution before yeasting. By dividing the assumed glomerular filtration rate by the volume of urine in ml. per minute the approximate dilution factor is obtained which will reduce-the concentration in urine to that simultaneously present in serum. If the latter value can be approximately estimated, the dilution factor can be adjusted to bring the concentration of mannitol in the diluted urine to lie between 50 and $150 \mathrm{mgm}$. per cent; further dilution or fortification is thereby avoided.

The net urine blank which must be subtracted to obtain an accurate estimation of the concentration of mannitol in urine, presents some difficulty when different urine samples are collected over intervals of time. The blank concentration of non-fermentable reducing substances varies from that in the initial specimen as the rate of urine flow varies and probably as the subject changes from a fasting to a post-prandial state. The most accurate value for the urine blank for each urine specimen $\left(C_{2}\right)$, therefore would appear to be the blank concentration in the initial blank specimen $\left(C_{1}\right)$ multiplied by a factor consisting of the rate of urine flow of the initial specimen $\left(V_{1}\right)$ divided by that of the subsequent specimen $\left(V_{2}\right)$ :

$$
\mathrm{C}_{2}=\frac{\mathrm{V}_{1} \mathrm{C}_{1}}{\mathrm{~V}_{2}}
$$

Equation 5

In an experiment on a normal fasting subject receiving no mannitol in which variations in rate of urine flow were induced over a range of 0.83 to $7.00 \mathrm{ml}$. per minute, the observed blank concentration differed from the proportional concentration, as calculated by the above equation, by less than $1 / 2$ the standard deviation of the method for urine. This method of calculating the net urine blank ralues between subjects can only be made in relation to rate of urine flow. In 8 blank urine specimens collected at various times under fasting conditions from the 3 normal subjects used in the present experiments, the average excretion rate of blank (non-fermentable reducing) substance was $1.9 \mathrm{mgm}$. per minute, with a range of 0.8 to $3.8 \mathrm{mgm}$. per minute.

To calculate the concentration of mannitol in urine, the reagent blank first must be subtracted from $M$ as calculated by Equation 2. The value so obtained for the diluted urine is then multiplied by the dilution factor and the net urine blank subtracted. This gives the net concentration of mannitol in the original sample of urine.

The results of the determination of mannitol in 12 known solutions in urine ranging from 168 to $5077 \mathrm{mgm}$. per cent were as follows: standard deviation $= \pm 88 \mathrm{mgm}$. per cent, average deviation $=72 \mathrm{mgm}$. per cent, maximum deviation $=168 \mathrm{mgm}$. per cent. When the deviation in each urine sample was divided by the dilution factor used, the average deviation was $2.7 \mathrm{mgm}$. per cent.

Summary. The modifications introduced into this method to improve its accuracy are listed as follows: (1) fortification of solutions containing low concentrations of mannitol, (2) cooling at $5^{\circ} \mathrm{C}$. of the partially reduced $\mathrm{KIO}_{4}$ solution between heating and titration, (3) avoidance of the use of dichromate cleaning solution in the titrating burette, (4) immersion titration using amylose rather than starch as an indicator, (5) calculation of the net urine blank from the rate of urine flow.

\section{EXPERIMENTAL PROCEDURE}

Three young male physicians in good health served as normal subjects. On arising in the morning the bladder was emptied and then $1 / 2$ to 1 hour later, just before the injection of mannitol, the bladder was again emptied yielding the urine specimen for blank determination. These normal subjects were not catheterized. The subjects were fasting until the end of the fourth hour after injection, food and fluids were then taken ad libitum. During the preliminary period for obtaining the blank urine specimen, 2 cups of black coffee were allowed; thereafter till the fourth hour, $100 \mathrm{ml}$. of water per $1 / 2$ hour were drunk immediately after each blood and urine collection.

The subjects were weighed stripped, $15 \mathrm{ml}$. of blood taken for the serum blank determination, and 12.0 to 25.9 grams of mannitol in a 25 per cent solution were injected intravenously from a calibrated syringe. ${ }^{2}$ At the end of each period the bladder was emptied and $15 \mathrm{ml}$. of venous blood were taken from the arm opposite to that in which the mannitol was given. During the entire experiment the subjects were on their feet doing their usual work around the laboratory. With the exception of Experiments 1 and 2 which were 5 days apart, the intervals between experiments in each subject ranged from 3 to 9 weeks.

One other "normal" subject (M. W.) is included in Table I. This patient was a control to the above 3 subjects in that he was catheterized and his bladder was washed at the time of each urine collection. He was a 25 year old negro male receiving penicillin therapy for latent lues but with a normal state of hydration as far as could be ascertained.

Two patients with excessive accumulations of body fluids served as abnormal subjects. Distribution studies were done by the same technique outlined above before and after removal of part of the excess fluid. Both patients were catheterized and the bladder washed at each urine collection. The chloride balance was determined for the periods between the mannitol distribution studies. Patient L. M. (Experiments 9 and 10) was a 55 year old white male with massive ascites due to portal cirrhosis and carcinoma of the liver who was studied before and after a paracentesis. Patient F. J. (Experiments 11, 12 , and 13) was a 60 year old white female with peripheral edema due to hypertensive heart disease. This patient on bed rest, digitalis, and a low salt diet, was given 6 grams of ammonium chloride daily and 3 intramuscular injections of Mercuhydrin. Mannitol distribution studies were done before and after the first mercurial injection and again at the end of a 10-day period during which she received 2 more injections.

\section{METHODS OF CALCULATION}

The apparent volume of distribution ( $\mathrm{V}$ ) of mannitol was calculated as follows:

$$
\mathrm{V}=\frac{\mathrm{A}}{\overline{\mathrm{C}}} \text {, }
$$


where $\mathrm{A}$ equals the net amount retained in the body, and $\mathrm{C}$ equals the concentration of mannitol in serum water. The serum water content was determined by direct weighing of serum before and after drying. The mannitol space $\left(E_{\mathbf{x}}\right)$ is taken to be that volume of distribution of mannitol which remains constant within experimental error between two points of determination.

Chloride concentration in serum was determined by the method of Hald (4) and in urine by the VolhardHarvey titration (5). The change in chloride space $\left(\Delta E_{c_{1}}\right)$ was calculated from the chloride balance (bor) and the extracellular water chloride concentrations $\left(\mathrm{Cl}_{1}\right.$ and $\mathrm{Cl}_{2}$ ) as described elsewhere (6), using the initial mannitol space $\left(E_{\mathbf{M}_{1}}\right)$ as $E_{1}$ :

$$
\begin{aligned}
\mathrm{E}_{\mathrm{Cl}_{2}} & =\frac{\left(\mathrm{E}_{1} \mathrm{Cl}_{1}\right)+\mathrm{b}_{\mathrm{Cl}}}{\mathrm{Cl}_{2}}, \\
\Delta \mathrm{E}_{\mathrm{Cl}} & =\mathrm{E}_{\mathrm{Cl}_{2}}-\mathrm{E}_{1} .
\end{aligned}
$$

\section{RESULTS IN NORMAL SUBJECTS}

Recovery of mannitol. In 3 experiments in 2 subjects the mannitol recovered in the urine 8 hours after injection was 89,93 , and 99 per cent of that injected; 24 to 26 hours after injection the recovery was 154,101 , and 108 per cent (Table I). Mannitol evidently was not destroyed. The greater than 100 per cent recovery at 24 to 26 hours is probably due to increased excretion of non-fermentable reducing substances after the fasting period (i.e., an unmeasurable increase in urine blank). Unpredictable changes in the urine blank in this period do not affect the calculation of volume of distribution of mannitol. It is unlikely that this increased blank is mannitol formed in the body, but direct proof of this is lacking.

Attainment of equilibrium. When the concentrations of mannitol in serum water are plotted semi-logarithmically against time after injection, the concentration at $1 / 2$ to $3 / 4$ hour lies above the straight line passing through the subsequent points, in 6 of the 8 experiments. That is, the rate of all in concentration was greater between $1 / 2$ hour and 1 hour than in the later periods. This is strong evidence that equilibrium in mannitol concentration was attained through the "mannitol space" between $1 / 2$ and 1 hour in these experiments. In Experiment 1, equilibrium appeared to have been reached by $1 / 2$ hour, and in Experiment 3 not until some time between 1 and $11 / 2$ hours. These variations may be related to the fact that it was in these experiments that the smallest and largest doses of mannitol, respectively, were given.

Volume of distribution. In 5 of the 8 experiments the volume of distribution of mannitol remained essentially unchanged between 1 and 3 hours after injection (Table I) ; after 3 hours the analytical error was too great to draw any conclusion. In 2 of the other experiments it appeared to expand. In Experiment 1, however, the small dose of mannitol rendered the error of the determination after 1 hour too large to be definitive. In Experiment 5 there was either a true but slight increase in the volume of distribution or the subject failed to empty his bladder completely. In Experiment 8 the volume of distribution was not determined after $11 / 4$ hours. In all of the experiments the distribution volume at $1 / 2$ hour was significantly lower than at 1 hour, due to the fact that equilibrium had not been attained (see above).

Agreement between the volumes of distribution at 1 hour after successive injections was remarkably good in each subject, the widest variations being not more than 0.06 per cent of the body weight or 4 per cent of the absolute volume. Uniformity between volumes of distribution of the different subjects at 1 hour was not so great; the range was 18.7 to 23.0 per cent of the body weight.

The error of the determination of the volume of distribution is complicated in that it is the resultant of 2 different analytical errors: those of serum and urine. If these 2 errors are in opposite directions they tend to cancel, if in the same direction they augment each other. Although there is 1 chance in 2 that the latter occurred in each instance, the degree of error in each volume of distribution has been calculated which would result from an error of the standard deviation in the same direction in serum and urine. The value thus obtained is designated as the maximum standard deviation error of the volume of distribution.

The nagnitude of the error so calculated at any one time is the direct resultant of the concentration of mannitol in serum and the concentration in, and volume of, urine. The lower the concentrations are or the larger the urine volume is, the greater is the error. Thus, the error is 
TABLE I

The volume of distribution and clearance of mannitol in normal subjects

\begin{tabular}{|c|c|c|c|c|c|c|c|c|c|c|c|c|c|c|c|}
\hline \multirow{2}{*}{$\begin{array}{c}\text { Experi- } \\
\text { ment }\end{array}$} & \multirow{2}{*}{ Subject } & \multirow{2}{*}{$\begin{array}{c}\text { Weight } \\
\text { and } \\
\text { surface } \\
\text { area }\end{array}$} & \multirow{2}{*}{$\begin{array}{c}\text { Time } \\
\text { after } \\
\text { injection } \\
\text { of man- } \\
\text { nitol }\end{array}$} & \multirow{2}{*}{$\begin{array}{c}\text { Man- } \\
\text { nitol } \\
\text { in- } \\
\text { jected }\end{array}$} & \multicolumn{2}{|c|}{ Urine } & \multirow{2}{*}{$\begin{array}{c}\text { Man- } \\
\text { nitol } \\
\text { net } \\
\text { retained }\end{array}$} & \multicolumn{2}{|c|}{ Serum } & \multirow{2}{*}{$\begin{array}{l}\begin{array}{c}\text { Serum } \\
\mathrm{H}_{2} \mathrm{O}\end{array} \\
\begin{array}{l}\text { Man- } \\
\text { nitol } \\
\text { conc. }\end{array}\end{array}$} & \multicolumn{3}{|c|}{$\begin{array}{l}\text { Volume of } \\
\text { distribution }\end{array}$} & \multicolumn{2}{|c|}{$\begin{array}{l}\text { Glomerular } \\
\text { filtration }\end{array}$} \\
\hline & & & & & $\begin{array}{l}\text { Vol- } \\
\text { ume }\end{array}$ & $\underset{\begin{array}{c}\text { Man- } \\
\text { nitol } \\
\text { content }\end{array}}{ }$ & & $\begin{array}{l}\text { Man- } \\
\text { nitol } \\
\text { conc. }\end{array}$ & $\begin{array}{l}\mathrm{H}_{2} \mathrm{O} \\
\text { con- } \\
\text { tent }\end{array}$ & & Vol. & $\begin{array}{l}\text { Max. } \sigma \\
\text { error* }\end{array}$ & Vol. & Rate & $\begin{array}{l}\text { Max. } \\
\text { error* }\end{array}$ \\
\hline 1 & R. E. & \begin{tabular}{|c|} 
kgm. \\
sq. $m$. \\
70.17 \\
1.84 \\
\end{tabular} & $\begin{array}{c}\text { hours } \\
0 \\
\frac{1}{2} \\
1 \\
2 \\
3 \\
24\end{array}$ & $\begin{array}{l}\text { grams } \\
12.95\end{array}$ & $\begin{array}{r}m l . \\
108 \\
84 \\
285 \\
174 \\
1,344\end{array}$ & $\begin{array}{r}m g m . \\
\\
3,145 \\
1,923 \\
2,475 \\
1,785 \\
10,565\end{array}$ & \begin{tabular}{|r|} 
mgm. \\
\\
9,805 \\
7,876 \\
5,397 \\
3,609 \\
$-6,959$
\end{tabular} & $\begin{array}{c}\text { mgm. } \\
\text { per. } \\
\text { cent } \\
\\
76.2 \\
55.9 \\
30.4 \\
19.1 \\
0.3\end{array}$ & $\begin{array}{c}\text { grams } \\
\text { per } \\
\text { liter } \\
932 \\
932\end{array}$ & \begin{tabular}{|r|} 
mgm. \\
per \\
liter \\
817 \\
600 \\
326 \\
205 \\
3
\end{tabular} & $\begin{array}{l}12.0 \\
13.1 \\
16.5 \\
17.6\end{array}$ & $\begin{array}{l} \pm 0.3 \\
\pm 0.4 \\
\pm 1.5 \\
\pm 2.1\end{array}$ & $\begin{array}{c}\begin{array}{c}\text { per cent } \\
\text { body } \\
\text { weight }\end{array} \\
17.1 \\
18.7 \\
23.5 \\
25.1\end{array}$ & $\begin{array}{r}m l . p e \\
\text { per } 1.7 . \\
\\
87 \\
92 \\
120\end{array}$ & $\begin{array}{l}\min . \\
\text { sq. } m . \\
\pm 4 \\
\pm 11 \\
\pm 11\end{array}$ \\
\hline 2 & R. E. & $\begin{array}{r}69.85 \\
1.83\end{array}$ & $\begin{array}{l}0 \\
\frac{1}{2} \\
1 \\
1 \frac{1}{2} \\
2 \\
3 \\
8\end{array}$ & 20.75 & $\begin{array}{r}102 \\
60 \\
58 \\
43 \\
81 \\
252\end{array}$ & $\begin{array}{l}4,780 \\
2,935 \\
2,292 \\
1,563 \\
2,440 \\
4,440\end{array}$ & $\begin{array}{r}15,970 \\
13,025 \\
10,726 \\
9,157 \\
6,712 \\
2,267\end{array}$ & $\begin{array}{r}122.3 \\
90.0 \\
73.4 \\
64.3 \\
39.2 \\
12.1\end{array}$ & $\begin{array}{l}935 \\
933\end{array}$ & $\begin{array}{r}1,307 \\
963 \\
787 \\
689 \\
420 \\
130\end{array}$ & $\begin{array}{l}12.2 \\
13.5 \\
13.6 \\
13.3 \\
16.0 \\
17.4\end{array}$ & $\begin{array}{l} \pm 0.2 \\
\pm 0.3 \\
\pm 0.3 \\
\pm 0.3 \\
\pm 0.7 \\
\pm 3.8\end{array}$ & $\begin{array}{l}17.5 \\
19.3 \\
19.5 \\
19.0 \\
22.9 \\
24.9\end{array}$ & $\begin{array}{l}88 \\
85 \\
75 \\
76 \\
61\end{array}$ & $\begin{array}{l} \pm 2 \\
\pm 4 \\
\pm 4 \\
\pm 3 \\
\pm 3\end{array}$ \\
\hline 3 & R. E. & $\begin{array}{r}70.78 \\
1.84\end{array}$ & $\begin{array}{l}0 \\
\frac{1}{2} \\
1 \\
1 \frac{1}{2} \\
2 \\
3 \\
8 \\
26\end{array}$ & 25.85 & $\begin{array}{r}124 \\
89 \\
100 \\
209 \\
250 \\
547 \\
928\end{array}$ & $\begin{array}{l}5,565 \\
3,885 \\
2,768 \\
2,172 \\
3,210 \\
6,470 \\
1,923\end{array}$ & $\begin{array}{r}20,285 \\
16,397 \\
13,610 \\
11,431 \\
8,215 \\
1,738 \\
-186\end{array}$ & $\begin{array}{r}156.6 \\
112.9 \\
88.2 \\
73.0 \\
52.4 \\
11.2 \\
2.7\end{array}$ & 933 & $\begin{array}{r}1,673 \\
1,207 \\
943 \\
781 \\
562 \\
120\end{array}$ & $\begin{array}{l}12.1 \\
13.6 \\
14.4 \\
14.6 \\
14.6 \\
14.5\end{array}$ & $\begin{array}{l} \pm 0.2 \\
\pm 0.2 \\
\pm 0.3 \\
\pm 0.5 \\
\pm 0.8 \\
\pm 5.0\end{array}$ & $\begin{array}{l}17.1 \\
19.2 \\
20.3 \\
20.6 \\
20.6 \\
20.5\end{array}$ & $\begin{array}{l}90 \\
87 \\
84 \\
81 \\
76\end{array}$ & $\begin{array}{l} \pm 2 \\
\pm 4 \\
\pm 9 \\
\pm 8 \\
\pm 7\end{array}$ \\
\hline 4 & J. R. & $\begin{array}{r}62.13 \\
1.73\end{array}$ & $\begin{array}{l}0 \\
\frac{1}{2} \\
1 \\
1 \frac{1}{2} \\
2 \\
3 \\
8 \\
25\end{array}$ & 20.75 & $\begin{array}{r}91 \\
85 \\
59 \\
62 \\
188 \\
282 \\
830\end{array}$ & $\begin{array}{l}4,770 \\
4,260 \\
2,410 \\
2,005 \\
2,810 \\
4,290 \\
1,792\end{array}$ & $\begin{array}{r}15,980 \\
11,710 \\
9,294 \\
7,284 \\
4,470 \\
175 \\
-1,618\end{array}$ & $\begin{array}{r}128.2 \\
80.7 \\
63.5 \\
49.7 \\
30.6\end{array}$ & $\begin{array}{l}937 \\
932\end{array}$ & $\begin{array}{r}1,367 \\
862 \\
679 \\
532 \\
329\end{array}$ & $\begin{array}{l}11.7 \\
13.6 \\
13.7 \\
13.7 \\
13.6\end{array}$ & $\begin{array}{l} \pm 0.2 \\
\pm 0.3 \\
\pm 0.3 \\
\pm 0.4 \\
\pm 1.1\end{array}$ & $\begin{array}{l}18.8 \\
21.9 \\
22.1 \\
22.1 \\
21.9\end{array}$ & $\begin{array}{l}119 \\
112 \\
120 \\
118\end{array}$ & $\begin{array}{l} \pm 4 \\
\pm 5 \\
\pm 6 \\
\pm 6\end{array}$ \\
\hline 5 & J. R. & \begin{tabular}{r|}
62.48 \\
1.73
\end{tabular} & $\begin{array}{l}0 \\
\frac{1}{2} \\
1 \\
1 \frac{1}{2} \\
2\end{array}$ & 25.85 & $\begin{array}{r}175 \\
121 \\
92 \\
69\end{array}$ & $\begin{array}{l}6,190 \\
4,220 \\
2,765 \\
2,100\end{array}$ & $\begin{array}{l}19,660 \\
15,429 \\
12,656 \\
10,550\end{array}$ & $\begin{array}{r}143.3 \\
102.7 \\
80.2 \\
61.9\end{array}$ & 934 & \begin{tabular}{|r|}
1,534 \\
1,100 \\
858 \\
663 \\
\end{tabular} & $\begin{array}{l}12.8 \\
14.0 \\
14.7 \\
15.9\end{array}$ & $\begin{array}{l} \pm 0.2 \\
\pm 0.3 \\
\pm 0.4 \\
\pm 0.4\end{array}$ & $\begin{array}{l}20.5 \\
22.4 \\
23.5 \\
25.5\end{array}$ & $\begin{array}{r}115 \\
101 \\
97\end{array}$ & $\begin{array}{l} \pm 4 \\
\pm 5 \\
\pm 5\end{array}$ \\
\hline 6 & L. G. & $\begin{array}{r}67.63 \\
1.78\end{array}$ & $\begin{array}{l}0 \\
\frac{1}{2} \\
\frac{3}{2} \\
1 \frac{1}{2} \\
2 \\
3\end{array}$ & 20.75 & $\begin{array}{l}86 \\
49 \\
50 \\
42 \\
67\end{array}$ & $\begin{array}{l}4,900 \\
2,855 \\
2,480 \\
1,802 \\
2,500\end{array}$ & $\begin{array}{r}15,850 \\
12,986 \\
10,500 \\
8,793 \\
6,289\end{array}$ & $\begin{array}{r}106.6 \\
79.0 \\
64.4 \\
53.9 \\
38.3\end{array}$ & 934 & \begin{tabular}{|r|}
1,138 \\
841 \\
687 \\
577 \\
410
\end{tabular} & $\begin{array}{l}13.9 \\
15.4 \\
15.3 \\
15.3 \\
15.3\end{array}$ & $\begin{array}{l} \pm 0.2 \\
\pm 0.3 \\
\pm 0.4 \\
\pm 0.4 \\
\pm 0.7\end{array}$ & $\begin{array}{l}20.5 \\
22.8 \\
22.6 \\
22.6 \\
22.6\end{array}$ & $\begin{array}{r}103 \\
109 \\
99 \\
9.0\end{array}$ & $\begin{array}{l} \pm 2 \\
\pm 4 \\
\pm 6 \\
\pm 5\end{array}$ \\
\hline 7 & L. G. & \begin{tabular}{|r|}
68.46 \\
1.79
\end{tabular} & $\begin{array}{l}0 \\
\frac{1}{2} \\
1 \\
1 \frac{1}{2} \\
2 \\
3\end{array}$ & 25.55 & \begin{tabular}{r|}
141 \\
84 \\
102 \\
112 \\
282
\end{tabular} & $\begin{array}{l}6,310 \\
3,890 \\
2,892 \\
2,320 \\
3,075\end{array}$ & $\begin{array}{r}19,240 \\
15,340 \\
12,441 \\
10,115 \\
7,035\end{array}$ & $\begin{array}{r}126.5 \\
90.9 \\
72.3 \\
58.8 \\
39.0\end{array}$ & 930 & $\begin{array}{r}1,357 \\
975 \\
778 \\
632 \\
419\end{array}$ & $\begin{array}{l}14.2 \\
15.7 \\
16.0 \\
16.0 \\
16.8\end{array}$ & $\begin{array}{l} \pm 0.3 \\
\pm 0.3 \\
\pm 0.4 \\
\pm 0.5 \\
\pm 1.2\end{array}$ & $\begin{array}{l}20.8 \\
23.0 \\
23.4 \\
23.4 \\
24.6\end{array}$ & $\begin{array}{l}121 \\
114 \\
115 \\
102\end{array}$ & $\begin{array}{l} \pm 3 \\
\pm 6 \\
\pm 8 \\
\pm 12\end{array}$ \\
\hline 8 & M. W. & 62.20 & $\begin{array}{l}0 \\
\frac{3}{4} \\
1 \\
11\end{array}$ & 25.75 & $\begin{array}{r}365 \\
89 \\
128\end{array}$ & $\begin{array}{l}8,920 \\
1,570 \\
1,680\end{array}$ & $\begin{array}{l}16,819 \\
15,241 \\
13,554\end{array}$ & $\begin{array}{r}132.6 \\
101.9 \\
88.4\end{array}$ & 932 & $\begin{array}{r}1,423 \\
1,093 \\
949\end{array}$ & $\begin{array}{l}11.8 \\
14.0 \\
14.3\end{array}$ & $\begin{array}{l} \pm 0.4 \\
\pm 0.3 \\
\pm 0.3\end{array}$ & $\begin{array}{l}19.0 \\
22.5 \\
23.0\end{array}$ & $\begin{array}{r}89 \\
116\end{array}$ & $\begin{array}{l} \pm 5 \\
\pm 8\end{array}$ \\
\hline
\end{tabular}

* Maximum standard devation error (see text). 
greater with a smaller dose of mannitol (Experiment 1) than with a larger dose. Given approximately the same dosage, the lower the amounts of mannitol retained, the lower are the concentrations in serum and urine, and hence the greater is the error. In Experiments 2 to 8, inclusive, in normal subjects the maximum standard deviation error of the volume of distribution does not exceed \pm 0.5 liter until only 44 per cent or less is retained; after this period the error greatly increases in magnitude. Finally, given the same dosage and the same proportion of mannitol retained, the larger the urine volume the greater the error (Experiments 8 to 12).

For the volumes of distribution calculated at 1 hour after injection of 20.7 to 25.9 grams of mannitol, the average maximum standard deviation error was \pm 0.3 liter or \pm 2.1 per cent of the volume calculated. In these experiments the deviation from uniformity of the calculated volumes of distribution between 1 and 8 hours after injection could be explained by this maximum standard deviation error, with 2 exceptions only (Experiment 2, 3 hours, and Experiment 5, 2 hours).

Glomerular filtration rate. The mannitol clearance or glomerular filtration rate in the 3 subjects ranged from 75 to $121 \mathrm{ml}$. per minute per 1.73 square meters of body surface (Table I). These values are considerably below those given by Goldring and Chasis (7) for normal males, namely, $131 \pm 22 \mathrm{ml}$. per minute per 1.73 square meters, but our subjects were not at rest. The maximum standard deviation error for the 1 to $11 / 2$ hour periods averaged $\pm 5 \mathrm{ml}$. per minute or \pm 4.8 per cent of the clearance, and increased as the excretion rate diminished.

\section{RESULTS IN ABNORMAL SUBJECTS}

Attainment of equilibrium. In the 2 subjects with abnormal accumulation of body fluid, as might be predicted, equilibrium throughout the mannitol space was not reached as soon as in the normal subjects (Table II). In the patient with ascites, equilibrium apparently was not reached at 4 hours after injection in Experiment 9, before paracentesis; or at 3 hours in Experiment 10, after paracentesis. In Experiment 9 the concentration of mannitol in ascitic fluid water was determined directly at $41 / 2$ hours and found to be $50.4 \mathrm{mgm}$. per cent; the concentration in serum water at 4 hours was $52.3 \mathrm{mgm}$. per cent. These findings suggest that equilibrium actually had been reached at 4 hours but was not confirmed by a subsequent point. In the patient with cardiac edema, equilibrium appeared to be attained at 4,3 and 2 .hours after injection as the edema progressively diminished.

Volume of distribution. In both of these subjects before any removal of excess fluid, the mannitol space or volume of distribution, after approximate equilibrium had been reached, was a much larger proportion of the total body' weight than it was in the normal subjects, namely 37.6 per cent of the body weight in L. M. with ascites and 40.7 per cent in F. J. with cardiac edema (Table II).

In both patients the change in mannitol space $\left(\Delta \mathrm{E}_{\mathbf{M}}\right)$ was compared with the change calculated for the chloride space $\left(\Delta \mathrm{E}_{\mathrm{Cl}}\right)$. In patient L. $\mathrm{M}$. the volume of cell-free ascitic fluid removed by paracentesis was 4.9 liters, $\Delta \mathrm{E}_{\mathrm{Cl}}$ was -4.9 liters, and $\Delta \mathrm{E}_{\mathbf{M}}$ was -3.0 maximum $\sigma$ error \pm 0.7 liter. In patient $F$. J. the check between $\Delta E_{M}$ and $\Delta \mathrm{E}_{\mathrm{Cl}}$ was very good for Experiments 11 and 12 which were done before and immediately after the first mercurial diuresis. $\Delta \mathrm{E}_{\mathrm{Cl}}$ was -5.6 liters and $\Delta \mathrm{E}_{\mathrm{M}}$ was -6.0 maximum $\sigma$ error \pm 0.8 liter. The agreement between the 2 in Experiments 12 and 13, done 10 . days apart, was not so close, $\Delta \mathrm{E}_{\mathrm{Cr}}$ being -5.3 liters and $\Delta \mathrm{E}_{\mathrm{M}}$ being -6.9 liters. The agreement of $\Delta \mathrm{E}_{\mathrm{M}}$ with the change in weight, $-6.6 \mathrm{kgm}$., was better, and suggested that a cumulative positive error existed in the chloride balance, probably due to failure of complete absorption of the 6 grams of enteric coated $\mathrm{NH}_{4} \mathrm{Cl}$ ingested daily. Such an error, of course, would be considerably less in the 24-hour period between Experiments 11 and 12. It should be noted that between Experiments 11 and 13 in which period $\Delta \mathrm{E}_{\mathbf{M}}=-12.9$ liters, the patient's $4+$ pitting edema of the legs, sacrum and lower abdominal wall almost completely disappeared.

Glomerular filtration rate. The range of the mannitol clearance, 35 to $69 \mathrm{ml}$. per minute per 1.73 square meter, was definitely lower in these 2 patients than in the normal subjects. No change in clearance occurred in patient L. M. be- 
TABLE II

The volume of distribution and clearance of mannitol in subjects with abnormal accumulations of body fuids

\begin{tabular}{|c|c|c|c|c|c|c|c|c|c|c|c|c|c|c|c|c|c|c|c|}
\hline \multirow{2}{*}{$\begin{array}{c}\text { Ex- } \\
\text { peri- } \\
\text { ment }\end{array}$} & \multirow{2}{*}{$\begin{array}{c}\text { Sub- } \\
\text { ject } \\
\text { and } \\
\text { weight }\end{array}$} & \multirow{2}{*}{ Date } & \multirow{2}{*}{$\begin{array}{c}\text { Time } \\
\text { after } \\
\text { injec- } \\
\text { tion } \\
\text { of } \\
\text { man- } \\
\text { nitol }\end{array}$} & \multirow{2}{*}{$\begin{array}{c}\text { Man- } \\
\text { nitol } \\
\text { in- } \\
\text { jected }\end{array}$} & \multicolumn{2}{|c|}{ Urine } & \multicolumn{2}{|c|}{ Ascitic fluid } & \multirow{2}{*}{$\begin{array}{l}\text { Man- } \\
\text { nitol } \\
\text { net } \\
\text { re-- } \\
\text { tained }\end{array}$} & \multirow{2}{*}{$\begin{array}{l}\text { Chlo- } \\
\text { ride } \\
\text { bal- } \\
\text { ance }\end{array}$} & \multicolumn{3}{|c|}{ Serum } & \multicolumn{2}{|c|}{$\begin{array}{l}\text { Glomerular } \\
\text { filtration }\end{array}$} & \multicolumn{2}{|c|}{$\begin{array}{c}\text { Mannitol } \\
\text { volume of } \\
\text { distribu- } \\
\text { tion }\end{array}$} & \multicolumn{2}{|c|}{ Change in: } \\
\hline & & & & & $\begin{array}{l}\text { Vol- } \\
\text { ume }\end{array}$ & $\begin{array}{l}\text { Man- } \\
\text { nitol } \\
\text { con- } \\
\text { tent }\end{array}$ & $\begin{array}{l}\text { Vol- } \\
\text { ume }\end{array}$ & $\begin{array}{l}\text { Man- } \\
\text { nitol } \\
\text { conc. }\end{array}$ & & & $\begin{array}{l}\text { Man- } \\
\text { nitol } \\
\text { conc. }\end{array}$ & $\begin{array}{l}\text { Chlo- } \\
\text { ride } \\
\text { conc. }\end{array}$ & $\begin{array}{l}\mathrm{H}_{2} \mathrm{O} \\
\text { con- } \\
\text { tent }\end{array}$ & Rate & $\begin{array}{l}\text { Max. } \\
\text { error* }\end{array}$ & Vol. & Max. & $\begin{array}{c}\text { Man- } \\
\text { nitol } \\
\text { space }\end{array}$ & $\begin{array}{l}\text { Chlo- } \\
\text { ride } \\
\text { space }\end{array}$ \\
\hline & kgm. & . & hours & grams & $m l$. & $m g m$. & $m l$ & $\begin{array}{c}\text { mgm. } \\
\text { per } \\
\text { cent }\end{array}$ & mgm. & m. eq. & $\begin{array}{c}\text { mgm. } \\
\text { per } \\
\text { cent }\end{array}$ & $\begin{array}{c}\text { m. eq. } \\
\text { per } \\
\text { liter }\end{array}$ & $\begin{array}{c}\text { grams } \\
\text { per } \\
\text { liter }\end{array}$ & \multicolumn{2}{|c|}{$\begin{array}{c}\text { ml. per min. } \\
\text { per } 1.73 \\
\text { sq. } m .\end{array}$} & & iters & \multicolumn{2}{|c|}{ liters } \\
\hline
\end{tabular}

Patient with ascites due to cirrhosis and carcinoma of liver: before and after paracentesis

\begin{tabular}{|c|c|c|c|c|c|c|c|c|c|c|c|c|c|c|c|c|c|c|c|}
\hline 10 & $\begin{array}{l}\text { L. M. } \\
61.2 \\
56.4\end{array}$ & $\begin{array}{l}\text { Dec. } 5 \\
\text { Dec. } 6\end{array}$ & $\begin{array}{l}0 \\
1 \\
2 \\
3 \\
4 \\
4 \\
0 \\
1 \\
2 \\
3\end{array}$ & $\begin{array}{l}25.45 \\
22.85\end{array}$ & $\begin{array}{r}137 \\
68 \\
65 \\
56 \\
415 \\
160 \\
67 \\
80\end{array}$ & $\begin{array}{l}5,965 \\
3,120 \\
2,590 \\
1,730 \\
\\
\\
6,780 \\
2,295 \\
2,480\end{array}$ & $\begin{array}{r}30 \\
4,900 \dagger\end{array}$ & $\begin{array}{l}43.9 \\
49.1\end{array}$ & $\begin{array}{l}19,485 \\
16,357 \\
13,748 \\
12,013 \\
\\
16,070 \\
13,767 \\
11,283\end{array}$ & $\coprod_{-518}$ & \begin{tabular}{|r|}
101.6 \\
76.4 \\
59.9 \\
48.5 \\
\\
\\
86.7 \\
68.0 \\
52.2
\end{tabular} & $\begin{array}{l}94.6 \\
90.0\end{array}$ & $\begin{array}{l}928 \\
928 \\
927\end{array}$ & $\begin{array}{l}63 \\
63 \\
65 \\
\\
\\
69 \\
62\end{array}$ & $\begin{array}{l} \pm 1 \\
\pm 1 \\
\pm 2 \\
\pm 2 \\
\pm 2\end{array}$ & $\begin{array}{l}17.8 \\
19.9 \\
21.3 \\
23.0 \\
\\
17.2 \\
18.8 \\
20.0\end{array}$ & $\begin{array}{l} \pm 0.3 \\
\pm 0.4 \\
\pm 0.5 \\
\pm 0.7 \\
\\
\pm 0.4 \\
\pm 0.4 \\
\pm 0.6\end{array}$ & \rfloor$_{-3.0}$ & $\begin{array}{r}\downarrow \\
-4\end{array}$ \\
\hline
\end{tabular}

Patient with peripheral edema due to hypertensive heart disease: before and after mercurial diuresis

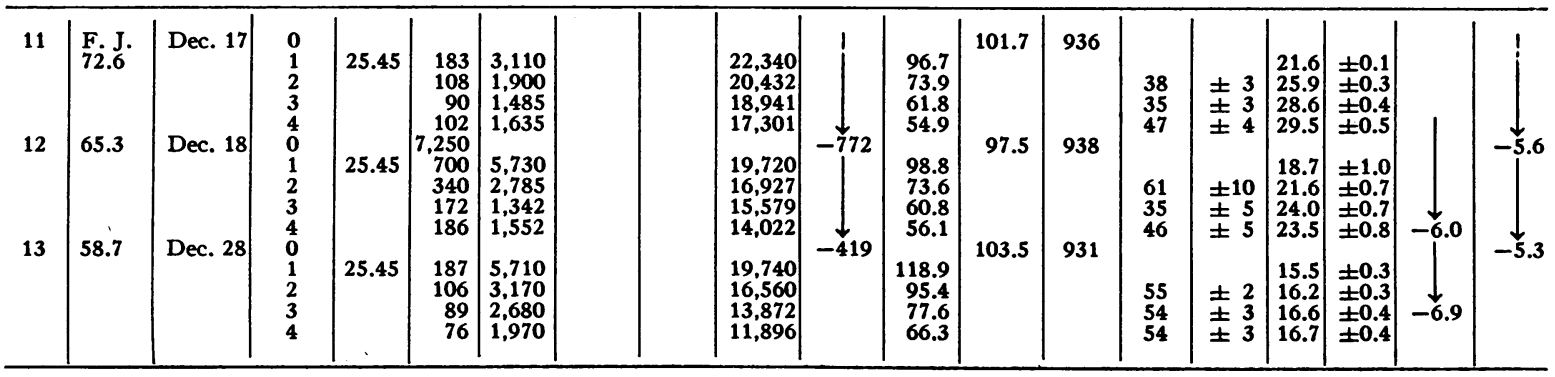

* Maximum standard deviation error (see text).

† Water content equaled 974 grams per liter.

fore and after paracentesis. However, in patient F. J. the clearance was higher in Experiment 13 when most of her edema had been removed.

\section{DISCUSSION}

The evidence presented in these experiments indicates that in the normal subject mannitol is distributed throughout a definite fraction of the body fluids. This fraction remains essentially constant between 1 and 3 hours after intravenous injection and is reproducible in the same subject after repeated injections. The assumptions necessary to the calculation of a constant volume of distribution, as outlined in the beginning of this paper, are supported by the data presented. Mannitol was completely recovered in urine. It appeared to be uniformly distributed throughout 1 portion of the body fluids, and the concentrations of mannitol in ascitic fluid checked very closely with that in serum, when equilibrium probably had been attained.

The time required in normal subjects for equilibrium to be reached between serum and the rest of the mannitol space was found in these experiments to lie between $1 / 2$ and 1 hour. This is definitely longer than the 20 minutes reported by Newman, Bordley, and Winternitz (2), but approximates the time of 1 hour reported by Alving and Miller (8) for inulin. Certainly for any measurement of the mannitol space it is essential that this equilibrium be reached, as indicated by a constant value for the volume of distribution between 2 separate points. In patients with abnormal accumulations of extracellular fluid, the time for equilibration may be greatly extended. In patient L. M. with ascites, it was only approached at 3 to 4 hours. In patient $F$. J. with edema, equilibrium was reached more rapidly as 
the edema and mannitol space diminished in size, namely, at 3 to 4 hours, 2 to 3 hours, and 1 to 2 hours (Experiments 11, 12, and 13).. Prolongation of the time for equilibration probably occurs in the presence of any type of circulatory impairment.

No direct evidence is presented regarding the relation between the absolute mannitol space and the extracellular fluid. In the normal subjects the magnitude of the former approximated the accepted value for the volume of the latter, namely, $1 / 5$ of the body weight. The range in these experiments was 18.7 to 23.0 per cent of the body weight. These values are slightly higher than the average for 11 normal subjects found by Newman, Bordley and Winternitz (2) which was 17.7 per cent of the body weight. The volume of distribution of sucrose, a similar polysaccharide, was shown by Lavietes, Bourdillon and Klinghoffer (9) to range in 3 normal subjects between 17.2 and 20.3 per cent of the body weight.

No one substance has ever been shown to be completely excluded from all body cells. Due to the relatively small amounts of chloride in tissues (10), radioactive chloride, $\mathrm{Cl}^{38}$, is probably the best reference substance yet found. In dogs the volume of distribution of $\mathrm{Cl}^{38}$ has been demonstrated to be smaller than those of radioactive sodium, $\mathrm{Na}^{24}$, and sulfocyanate (11). However, the very short life of $\mathrm{Cl}^{38}$ makes it an extremely difficult substance to use experimentally. The author knows of only 1 human subject in whom the volume of distribution of $\mathrm{Cl}^{38}$ has been determined: the value obtained by Moore (12) was 18.9 per cent of the body weight. As the volume of distribution of $\mathrm{Na}^{24}$ in the same subject was 26.5 per cent of the body weight, it is obvious that radioactive sodium is no more useful as a reference substance in man than in the dog. Kaltreider, Meneely, Allen and Bale (13) obtained an average value of 24.8 per cent of body weight in 14 normal subjects for the volume of distribution of $\mathrm{Na}^{24}, 3$ hours after injection. This value is close to that of Moore's stated above. In the absence of a simultaneous study of the volumes of distribution of $\mathrm{Cl}^{38}$ and of mannitol in the same subjects, it can only be stated that the range of mannitol volumes of distribution found in our experiments lies between those of $\mathrm{Cl}^{88}$ and
$\mathrm{Na}^{24}$ as found by these other workers in other subjects. This is hardly definitive.

Studies of the phase distribution of sugars in individual tissues have not been extensive. Mannitol does not penetrate erythrocytes $(1,2)$. Wilde (14) demonstrated that inulin and sucrose were confined to a phase in skeletal muscle smaller than that of chloride. These tissue studies appear to confirm the results of the volume of distribution studies as indicating that mannitol and allied polysaccharides are in the main confined to extracellular fluid.

Another type of evidence is available in our experiments on the patients with ascites and edema. The change in mannitol space approximated the change in chloride space as calculated from the balances of and changes in serum concentration of chloride. This evidence does not indicate that the absolute size of the mannitol space is the same as that of chloride (11), but it does suggest that determination of the mannitol space may be a useful and independent measure of changes in extracellular fluid volume. Furthermore calculation of such change from the changes in balance and serum concentrations of chloride is possible only if the initial extracellular fluid volume, $E_{l}$, is known. In a normal subject this value can be estimated reasonably from the body weight. But in patients with dehydration or edema some direct measurement of $E_{1}$ is necessary. Direct determination of the mannitol space may be used for this purpose.

Successive determinations of the volume of distribution of mannitol in the same subject require some consideration of the rate of excretion of this substance. The rapidity of excretion probably prevents the detection of significant changes in the extracellular fluid volume between multiple points determined, following a single injection. On the other hand, the substance must be completely excreted before volumes of distribution can be determined following a second injection. Residual amounts in the serum and urine would introduce an unknown error into the calculation of blank concentrations, and hence into the calculation of the distribution volume.

The errors have also been studied which are involved in the measurement of the mannitol clearance, or the rate of glomerular filtration. 
Theoretically, when the mannitol clearance is calculated for the $1 / 2$ - to 1 -hour period, when the serum concentration of mannitol is higher than that in the interstitial fluid, it does not measure the glomerular filtration rate alone. Part of the removal of mannitol from the plasma is extrarenal and hence the clearance value should be higher than the true renal clearance. The data in Table I, however, reveal that the clearances in this period were not significantly higher than the succeeding period (with the possible exception of Experiment 5). Failure to reach complete equilibrium, therefore, did not introduce a significant error into the determination of the rate of glomerular filtration.

Newman, Bordley, and Winternitz (2) propose to calculate the clearance of mannitol from the rate of fall in serum concentration only, thus obviating the necessity of accurate urine collections and analyses. To do so, however, the volume of the extracellular fluid or mannitol space must be known. No other method of measuring extracellular fluid volume appears to be readily available, and its measurement by determination of the volume of distribution of mannitol requires the analysis of urine for mannitol.

These workers also state the opinion that the mannitol clearance or glomerular filtration rate is more significant physiologically if it is quantitated per unit of extracellular fluid volume than per unit of body surface or merely per unit of time. This seems to the author to be erroneous in that the size of the reservoir containing a substance to be excreted has no relation to rate at which the kidney is able to excrete it. The kidney can only act on that portion of the extracellular fluid volume which runs through it, the plasma. Thus in comparing the mannitol clearance between 2 and 3 hours after injections in Experiments 11 and 13 , in terms of ml. per minute it rose from 35 to 49 ( +40 per cent); in terms of $\mathrm{ml}$. per minute per 1.73 square meters of surface area it rose from 35 to 54 ( +55 per cent); and in terms of ml. per minute per liter of extracellular fluid volume (mannitol space) it rose from 1.2 to $3.0(+150$ per cent). In each experiment it was the same pair of kidneys; i.e., per unit of kidney the change in filtration rate was only +40 per cent. Because the extracellular fluid volume happened to be reduced by almost $1 / 2$, it does not seem significant from the standpoint of renal function to correct the change in rate to +150 per cent.

\section{SUMMARY}

In normal human subjects following a single intravenous injection of mannitol:

1. Mannitol was fully recovered in the urine in 24 hours.

2. Equilibrium appeared to be complete between $1 / 2$ and 1 hour after injection.

3. The volume of distribution was constant between 1 and 3 hours after injection, ranged between 18.7 and 23.0 per cent of the body weight, and was reproducible in each subject following repeated injections.

4. Under specified conditions the maximum standard deviation error in the volume of distribution did not exceed \pm 0.5 liter.

In 2 patients with ascites and edema following a single injection of mannitol:

1. Four hours or more were required for diffusion to equilibrium.

2. Equilibration was speeded as edema was reduced.

3. The decrease in mannitol space compared favorably with the decrease in chloride space as produced by paracentesis and mercurial diuresis.

The glomerular filtration rates in both groups of subjects were determined. The error due to failure of attainment of complete equilibrium was less than that due to the analytical error.

The relation of the mannitol space to the extracellular fluid is discussed.

Certain modifications in the mannitol method are described.

\section{BIBLIOGRAPHY}

1. Smith, W. W., Finkelstein, N., and Smith, H. W., Renal excretion of hexitols (sorbitol, mannitol, and dulcitol) and their derivatives (sorbitan, isomannide, and sorbide) and of endogenous creatininelike chromogen in dog and man. J. Biol. Chem., 1940, 135, 231.

2. Newman, E. V., Bordley, J., III, and Winternitz, J., The interrelationships of glomerular filtration rate (mannitol clearance), extracellular fluid volume, surface area of the body, and plasma concentration of mannitol: a definition of extracellular 
fluid clearance determined by following plasma concentration after a single injection of mannitol. Bull. Johns Hopkins Hosp., 1944, 75, 253.

3. Winkler, A. W., and Smith, P. K., The a'parent volume of distribution of potassium injected intravenously. J. Biol. Chem., 1938, 124, 589.

4. Hald, P. M. in Peters, J. P., and Van Slyke, D. D., Quantitative Clinical Chemistry. Williams and Wilkins, Baltimore, 1932, Vol. II, Methods, p. 838.

5. Harvey, S. C., The quantitative determination of the chlorides in the urine. Arch. Int. Med., 1910, 6, 12.

6. Elkinton, J. R., and Winkler, A. W., Transfers of intracellular potassium in experimental dehydration. J. Clin. Invest., 1944, 23, 93.

7. Goldring, W., and Chasis, H., Hypertension and $\mathrm{Hy}-$ pertensive Disease. The Commonwealth Fund, New York, 1944.

8. Alving, H. S., and Miller, B. F., A practical method for the measurement of the glomerular filtration rate (inulin clearance). Arch. Int. Méd., 1940, 66, 306.
9. Lavietes, P. H., Bourdillon, J., and Klinghoffer, $K$. A., The volume of extracellular fluids of the body. J. Clin. Invest., 1936, 15, 261.

10. Manery, J. F., and Hastings, A. B., The distribution of electrolytes in mammalian tissues. J. Biol. Chem., 1939, 127, 657.

11. Winkler, A. W., Elkinton, J. R., and Eisenman, A. J., Comparison of sulfocyanate with radioactive chloride and sodium in the measurement of extracellular fluid. Am. J. Physiol., 1943, 139, 239.

12. Moore, F. D., Determination of total body water and solids with isotopes. Science, 1946, 104, 157.

13. Kaltreider, N. L., Meneely, G. R., Allen, J. R., and Bale, W. F., Determination of the volume of the extracellulor fluid of the body with radioactive sodium. J. Exp. Med., 1941, 74, 569.

14. Wilde, W. S., The chloride equilibrium in muscle. Am. J. Physiol., 1945, 143, 666.

15. Barker, H. G., and Clark, J. K., Effect of para-aminohippurate on mannitol determinations by periodateiodide-thiosulfate method. Proc. Soc. Exp. Biol. \& Med., 1947, 64, 120. 